\title{
Cloning and expression of recombinant thrombin in Escherichia coli JM109 (DE3)
}

\author{
Nhân dòng và biểu hiện thrombin tái tổ hợp trong E. coli JM109 (DE3) \\ Research article
}

Vu Thi Bich Ngoc, Nguyen Thi Thao, Chu Thi Hoa, Do Thi Tuyen*

Institute of Biotechnology, Vietnam Academy of Science and Technology, 18 Hoang Quoc Viet, Hanoi, Vietnam

\begin{abstract}
Prothrombin, a protein involved in blood coagulation, is a plasma glycoprotein composed of the Gla domain, two adjacent kringle domains, and a serine protease domain. Prothrombin is a thrombin precursor playing the important role in the coagulation physiological as well as pathological condition. Thrombin is the key to convert the fibrinogen into fibrin by switching activation of XIII factor, pushed plasminogen into plasmin, the develope of the fibroblast and helps the stabilization of thrombolysis. In this study, the prothrombin gene was $936 \mathrm{bp}$ in lengths and encoded 312 amino acids from bovine lung was optimized codon, was cloned in pET21a ${ }^{+}$vector and expression in E. coli, in order to replace traditional bandages having slow affect, reduce the cost of products, cater the comunity health. The results showed that initially the successful cloning and expression of recombinant prothrombin in E. coli JM109(DE3).
\end{abstract}

Prothrombin, 1 glycoprotein huyết tuoong liên quan tới quá trình đông máu gồm 2 vùng Gla, 2 vùng Kringle và 1 vùng serine protease. Prothrombin là tiền chất của thrombin có vai trò quan trong trong sinh lý đông máu cũng nhu tình trạng bệnh lý. Thrombin được xem nhu chì khóa để chuyển hóa fibrinogen thành fibrin bằng cách hoạt hóa các yếu tố đông máu nhu XIII, thúc đẩy chuyển plasminogen thành plasmin và kich thich tăng sinh các tế bào tơ (fibroblast), giúp ổn định quá trình làm tan huyết khối. Trong nghiên cứu, các gen prothrombin được tách dòng tù phổi bỏ có kích thuớc 936 bp, mã hóa cho 312 axit amin được tối ưu hóa codon, nhân dòng vào vector pET21a và biểu hiện trong E. coli. Muc đích của nghiên cưu nhằm tạo ra băng gạc cầm máu nhanh, giá thành rẻ, phuc vu sức khỏe cộng đồng và thay thể băng gạc truyền thống. Kết quả nghiên cứu bước đầu cho thấy đã nhân dòng và biểu hiện thành công prothrombin tái tổ hợp ở chủng E. coli JM109(DE3).

Keywords: fibrin, fibrinogen, prothrombin, thrombin

\section{Introduction}

Thrombin is a serine protease that belong to the group of hydrolytic enzymes have capable cutting $-\mathrm{CO} \sim \mathrm{NH}$ - links in the polypeptide molecules, protein and some similar substrates into free amino acids or smaller molecular peptides. Amino acid serine was used as activated center by serine protease. In the body, coagulation is controlled carefully to avoid serious consequence can be caused by blood clots such as myocardial infarction, stroke leads to death. So, initial thrombin exists in an inactive form called prothrombin and is activated when had the injury. Ater the activation of prothrombin into $\alpha$ - thrombin with molecular weight about $32 \mathrm{kDa}$ and cut own to $\beta$ - thrombin and $\alpha$ thrombin which are less active forms after the conversion of fibrinogen into fibrin.
Thrombin plays a crucial role in the conversion of fibrinogen into fibrin which are plasma protein engaged in the final stage of coagulation. In 1940, the purified thrombin was applied in surgery (Walter 1940) and used widely multiple. In USA, it was used for more than 1 million patients at a cost of 250 million dollars (Lawson 2006). It may be useful for controlling the bleeding from capillaries and small veins, but not efficient and is not indicated for arterial bleeding quickly and massively (Greenhalgh, Gamelli et al. 2009, Singla, Ballard et al. 2009). In USA, thrombin has been applied to the nano gauze to apply on wounds to stop the bleeding faster than conventional gauze. In the biochemistry, thrombin is a valuable biochemical tool because of high proteolysis. The cutting site (Leu-Val-Pro-ArgGly-Ser) includes linked domains in the recombinant protein's structure. After the purification of protein, thrombin is used for cutting on Arg-Gly linked sites to remove the His tags. 
Thrombin was isolated from bovine and buffalo appears have studied and applied in hemostasis process from XIX century to present with many labled patents in USA (Glover and Shaw 1971, Silbering, Blythe et al. 1990, OVERHOLSER and Woodell-May 2015). Also, thrombin was extracted from human plasma and snake venoms (Markland and Damus 1971, Fenton, Fasco et al. 1977, Naski, Lorand et al. 1991, Aizawa, Winge et al. 2008, D.Zaqueo, Kayano et al. 2014). In the present study, we cloned a thrombin cDNA from bovine liver. The new prethrombin gene was expressed in E. coli, recovered, further, purified with a nickel-chelating resin column and assay the initial conversion of fibrinogen into fibrin. Results showed that recombinant prethrombin with molecular weight about $37 \mathrm{kDa}$ have been obtained and has activity of conversation. The results may lead to the development of new approach for the treatment of hemostasis to replace the traditional methods.

\section{Materials and Methods}

\subsection{Chemicals and reagents}

Bovine liver tissue, bovine fibrinogen was obtained from the Laboratory of Enzyme (IBT, VAST). Yeast extract, peptone, dNTPs, EcoRI, XhoI, T 4 ligase, dNTP set, Taq polymerase, RNase, GeneRuler ${ }^{\mathrm{TM}} 1 \mathrm{~kb}$ DNA Ladder, bacto tryptone, agar, ampicillin, IPTG, lysozym, protein MW were purchased from Bio Basic Inc. (Ontario, Canada) and Fermentas Corp. (USA). Kit ProBond ${ }^{\mathrm{TM}}$ Nickel-Chaleting Resin and Kit SuperScipt ${ }^{\mathrm{TM}}$ First - StrDNA Synthsis System for RT-PCR, IPTG were from Invitrogen Corp. (Carlsbad, CA, USA) and some other chemical such as potassium phosphate, tris- $\mathrm{HCl}$, sodium acetate from Merck (Germany). Primers was designed based on cDNA sequence of thrombin publishing on Genbank and was synthesized by Invitrogen Corp. (USA).

\subsection{Vectors, strains and culture conditions}

Expression vector $\mathrm{pET} 21 \mathrm{a}^{+}$contained prethrombin gene. E. coli host strain DH10B and JM109(DE3) (Invitrogen Corp., Carlsbad, CA, USA) were used for cloning and expression of the prethrombin, respectively. Luria-Bertani (LB) containing $0.5 \%(\mathrm{w} / \mathrm{v})$ yeast extract, $1 \%(\mathrm{w} / \mathrm{v})$ peptone, $1 \% \mathrm{NaCl}, \mathrm{pH} 7-7.5$ was used for the cultivation of $E$. coli; LB agar contained additionally $1.5 \%(\mathrm{w} / \mathrm{v})$ agar and $100 \mu \mathrm{g} / \mathrm{ml}$ ampicillin.

\subsection{RT-PCR amplification and gene cloning}

The total RNA was isolated from bovine liver tissue by using the extract Kit according to the manufacturer's instructions. The reaction of first-strand cDNA synthesis was catalyzed by reverse transcriptase using random primers. A reaction product of $3 \mu \mathrm{l}$ was added in the $25 \mu \mathrm{l}$ PCR amplification system. The primers were as follows forward primer and reverse primer. Prethrom-F: 5'gcgaattcatcgagggacgcacg-3' and Prethrom-R: 5'-gcctcgagacttcctaaccgatcaa-3'. PCR reaction were catalyzed by Taq DNA polymerase $(5 \mathrm{U} / \mu \mathrm{l})$ and the product was digested with $X h o$ I and EcoRI, and the DNA fragment including the ORF was ligated into vector $\mathrm{pET} 21 \mathrm{a}^{+}$to get $\mathrm{pEThr}$ vector.

\subsection{Expression of the recombinant $\mathrm{pEThr}$}

Overnight culture of cells bearing the construct for expression was dilute $1 \%$ into fresh LB broth in the presence of $100 \mu \mathrm{g} / \mathrm{ml}$ ampicillin. When the cell suspension reached an absorbance of 0.6- 0.8 at $600 \mathrm{~nm}$, the expression was induced by the addition of $1 \mathrm{mM}$ IPTG for $6 \mathrm{~h}$. Cells were harvested by centrifugation at $4000 \mathrm{rpm}$ for $10 \mathrm{~min}$ and resuspended in lysis buffer. The cells were sonicated on ice bath and the lysate was centrifuged at $12500 \mathrm{rpm}$ for 10 min. Cells was dissolved in 50mM Tris- $\mathrm{HCl}$ buffer contained $8 \mathrm{M}$ Urea. Expression of the fusion protein was analyzed by SDS- PAGE.

\subsection{Purification of the recombinant pEThr}

The inclusion body was dialysised in $50 \mathrm{mM}$ Tris $\mathrm{HCl}, \mathrm{pH}$ 8.0 to remove urea and dialysis sample was replaced the buffer for 1 time every 2 hours. After 3 times, samples were centrifuged $12500 \mathrm{rpm}$ for $30 \mathrm{~min}$ to receive the supernatant. The sample was loaded onto His-Bind Column $(10 \mathrm{~cm}$ glass column with $2 \mathrm{ml}$ of $\mathrm{Ni}$-agarose) pre-equilibrated with denatured buffer (50 mM NaH${ }_{2} \mathrm{PO}_{4}, 0,5 \mathrm{M} \mathrm{NaCl}, 10$ $\mathrm{mM}$ imidazole, $\mathrm{pH} 8,0$ ) at a rate of $1 \mathrm{ml} / 5 \mathrm{~min}$ for twice. The column was washed with $8 \mathrm{ml}$ washing denatured buffer for 3 times. Recombinant prethrombin was pushed out of the column with $8 \mathrm{ml}$ eluted denatured buffer. The results showed on SDS-PAGE and dying with the Coomassie blue were performed according to Sambrook and Russell.

\subsection{Analysis the conversion of fibrinogen into fibrin}

The activity of purified thrombin was analyzed by the conversion of fibrinogen into fibrin in the reaction included 20 $\mu \mathrm{l}$ fibrinogen, $200 \mu \mathrm{l} \mathrm{NaCl} 0.9 \%$ and $50 \mu \mathrm{l}$ thrombin. Control sample has no thrombin. Time of transformation of fibrinogen solution into fibrin strands was observed.

\section{Results and discussion}

\subsection{Amplification of prethrombin gene from liver bovine tissue}

The total RNA extracting from bovine liver was extracted by RNA purification Kit. Content of total RNA reached $328 \mu \mathrm{g} / \mathrm{ml}$ and the A260/280 value reached 2.02. The results showed that total RNA was purified successful and was used in other studies.

RT-PCR reaction was performed as described in the method section. Figure 1 (lane 3) shows a specific DNA fragment about $1000 \mathrm{bp}$ in size, in correspondence with the theoretical size of prethrombin is $936 \mathrm{bp}$.

The sequence of DNA fragment was analyzed by BLAST data. The data indicated the DNA fragment are cloned is gene coding for prethrombin is composed 936 nucleotides to encode a polypeptide of 312 amino acid residues (Fig. 2). 
In addition, BLAST analysis revealed that the DNA fragment encoding prethrombin has high homology reached 98-99\% compared with some published sequences.
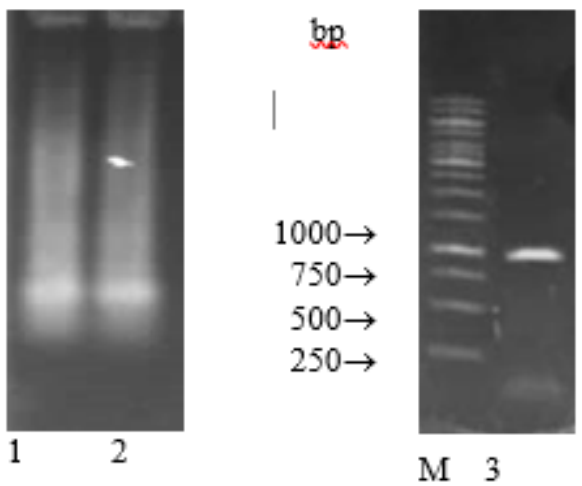

Figure 1. The agarose gel electrophoresis of total RNA from bovine liver $(1,2)$ and PCR products of prethrombin gene (3)

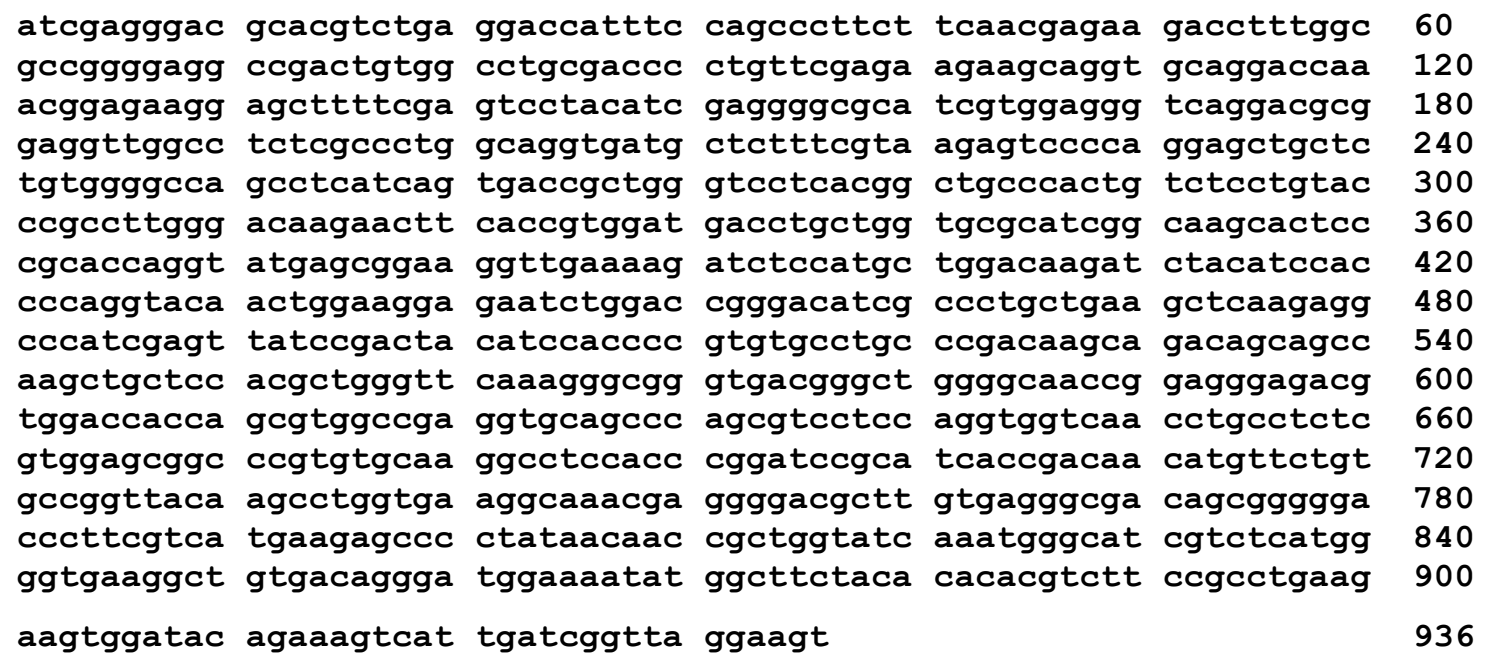

Figure 2. Sequence of the cDNA encoding prethrombin

\subsection{Construction of recombinant expression vector pEThr}

The resulting PCR product and $\mathrm{pET} 21 \mathrm{a}^{+}$were digested with EcoRI/XhoI, inserted into the pEThr plasmid and transformed into E. coli JM109 (DE3). Overnight incubation of this strain in LB agar contained $100 \mu \mathrm{g} / \mathrm{ml}$ ampicillin. Plasmid was extracted from some selected clonies. The results show the recombinant plasmids were higher than pET2 $1 \mathrm{a}^{+}$plasmid in size, they may be due to contain the inserted prethrombin gene. These plasmids were digested again with EcoRI/XhoI to check exactly insertion of prethrombin gene. The figures showed a band with size was approximately $1000 \mathrm{bp}$ of prethrombin gene and 5500 bp of pET2 $1 \mathrm{a}^{+}$plasmid (Figure 3). So, prethrombin gene was inserted into pET21a ${ }^{+}$.

\subsection{Expression of recombinant prothrombin}

The recombinant $\mathrm{pEThr}$ plasmid was transformed into E.coli JM109 (DE3) by chemical method to get the recombinant strains (JMThr). The pET21a+ was also transformed into E.coli JM109 (DE3) to get the control sample (pET21a+/JM109). These strains contained prothrombin gene was cultured in LB medium added to $100 \mathrm{ug} / \mathrm{ml} \mathrm{am-}$ picillin and induced with $1 \mathrm{mM}$ IPTG. In the SDS-PAGE gel, a protein band about $37 \mathrm{kDa}$ appeared after $6 \mathrm{~h}$ induction and the molecular mass agrees with the theoretical estimate based on the size of pEThr (Figure 4).
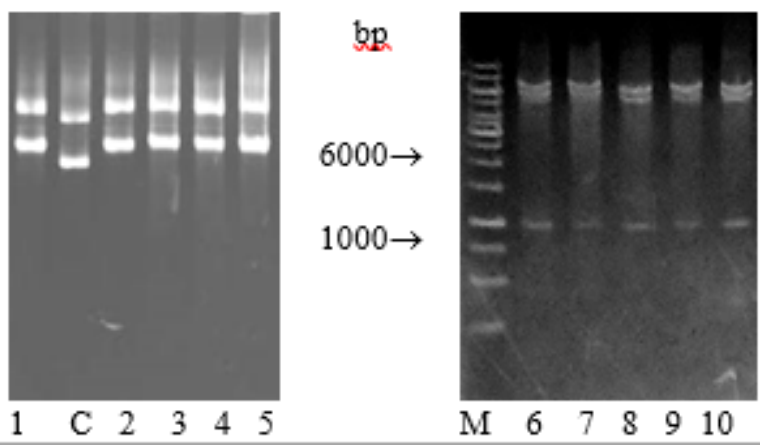

Figure 3. The agarose gel electrophoresis of recombinant plasmid pEThr (lane 1-6) and the digested products with EcoRI/XhoI (lane 6-10); pET21a ${ }^{+}$plasmid (lane C) 


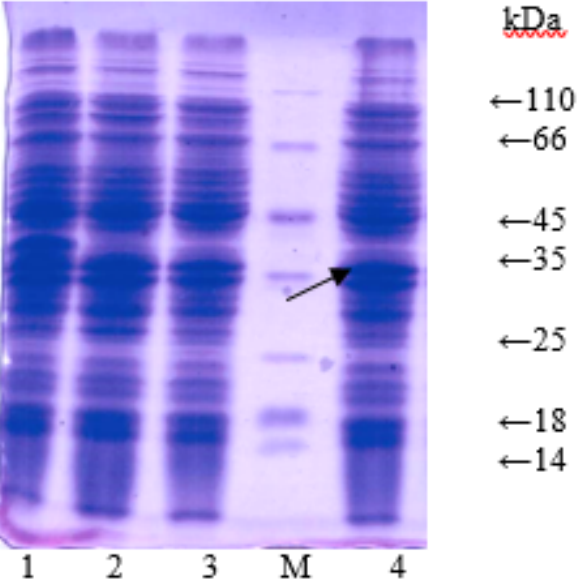

Figure 4. Analysis of the expression of recombinant prethrombin by SDS-PAGE. Total protein of JMThr at Oh (lane 2) and after $6 \mathrm{~h}$ induction (lane 1); total protein

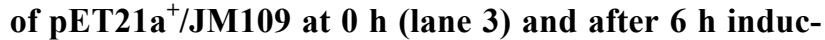
tion (lane 4); low molecular mass protein standards (lane M)

On the other hand, after the induction of expression, the cells were treated in $0.1 \mathrm{M}$ Tris $\mathrm{HCl}$ buffer, $\mathrm{pH} 8.0$ added lysozyme and then were sonicated on ice bath and the lysate was centrifuged, both of supernatant and pellet were analyzed by SDS-PAGE. The result shows the induced protein existed in the inclusion bodies (Figure 5). This outcome is similar with one of study of Dibella et al. (1995) (Dibella, Maurer et al. 1995).

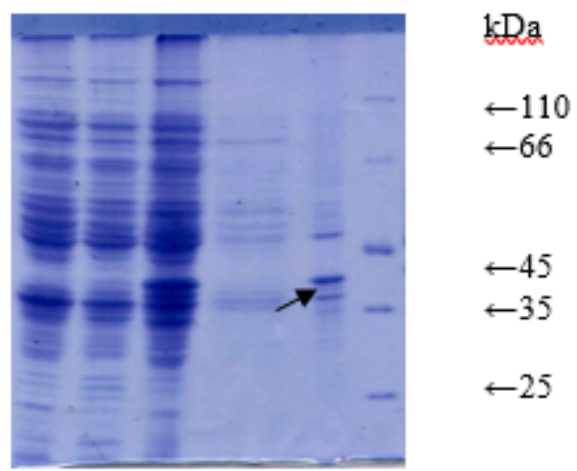

Figure 5. Analysis of the pellet protein and the supernatant of the lysate by SDS-PAGE Total protein of pET21a $^{+} / J M 109$ (lane 1), JMThr before the induction (lane 2) and after $6 \mathrm{~h}$ induction (lane 3); the cleared lysate (lane 4) and the pellet (lane 5).

\subsection{Purification of recombinant prethrombin}

The cells of $E$. coli JMThr strain were sonicated to get the inclusion bodies containing prethrombin. The pellets were dissolved in $8 \mathrm{M}$ Urea solution and dialysed in $50 \mathrm{mM}$ Tris$\mathrm{HCl}, \mathrm{pH}$ 8.0. After dialysis, the lysate was centrifuged to remove the pellets. The supernatant was used for purification using affnity chromatography. The results showed getting the soluble recombinant prethrombin (Figure 6A).

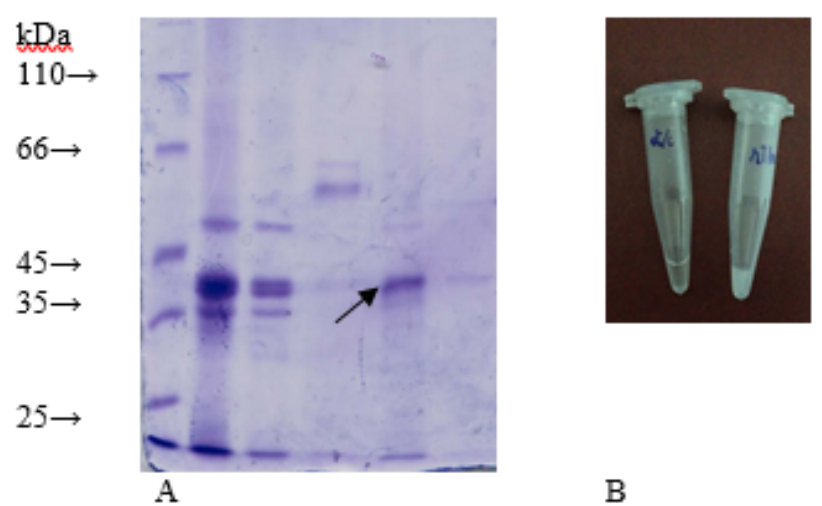

Figure 6. Analysis of purified prethrombin by SDSPAGE and the conversion of fibrinogen into fibrin (B) (lane 1: the supernatant; lane 2: the supernatant after binding; lane 3: the washing; lane 4-5: fractions 2 and 3; lane M: molecular weight marker

In previous studies, prethrombin was converted into thrombin by $\mathrm{Ca}^{2+}$. Then thrombin was measured the ability of conversion of fibrinogen. The result indicated that recombinant prethrombin has initial conversion of fibrinogen (fluid form) into fibrin (white condensed form) (Fig. 6B).

\section{Conclusions}

Here, the gene encoding thrombin were cloned from bovine liver and created the E. coliJM109(DE3) strain which expressed intracellular recombinant prethrombin to get $12 \%$ in yield of total cellular protein based on the analysis of expressed protein by Dolphin 1D sofware. The recombinant protein was purified using ion exchange chromatography columns $\mathrm{Ni}^{2}$. Prethrombin had initial activity to convert the fibrinogen into fibrin after the activation with $\mathrm{CaCl}_{2}$.

\section{Acknowledgement}

The study was supported by the Project of Institute of Biotechnology, Vietnam Academy of Science and Technology, (Project: CS16-04 "Study on expression conditions and purification of recombinant thrombin for application create rapid hemostatic dressings"), 2016-2017.

\section{References}

[1] Aizawa, P., et al. (2008). Large-scale preparation of thrombin from human plasma, Elsevier. 122: 560567.

[2] D.Zaqueo, K., et al. (2014). Isolation and biochemical characterization of a new thrombin-like serine protease from Bothrops pirajai Snake Venom. BioMed Research International 2014.

[3] DiBella, E. E., et al. (1995) Expression and folding of recombinant bovine prethrombin-2 and its activation to thrombin. J Biol Chem 270(1): 163-169.

[4] Fenton, J. W., et al. (1977). Human thrombins. Production, evaluation, and properties of alphathrombin, $A S B M B$ 252: 3587-3598.

[5] Glover, G. and E. Shaw (1971). The Purification of Thrombin and Isolation of a Peptide Containing the 
Active Center Histidine.Journal of Biological Chemistry 246(14): 4594-4601.

[6] Greenhalgh, D. G., et al. (2009). Recombinant thrombin: safety and immunogenicity in burn wound excision and grafting, $L W W 30: 371-379$.

[7] Lawson, J. H. (2006). The clinical use and immunologic impact of thrombin in surgery. Semin Thromb Hemost 1: 98-110.

[8] Markland, F. S. and P. S. Damus (1971). Purification and properties of a thrombin-like enzyme from the venom of Crotalus adamanteus (Eastern diamondback rattlesnake), $A S B M B$ 246: 6460-6473.

[9] Naski, M. C., et al. (1991). Characterization of the kinetic pathway for fibrin promotion of $\alpha$-thrombin catalyzed activation of plasma factor XIII. Biochemistry 30(4): 934-941.
[10] Overholser, H. and J. Woodell-May (2015). Thrombin isolated from blood and blood fractions, Google Patents.

[11] Silbering, S. B., et al. (1990). Purified thrombin preparations, Google Patents.

[12] Singla, N. K., et al. (2009). A phase 3b, open-label, single-group immunogenicity and safety study of topical recombinant thrombin in surgical hemostasis, Elsevier. 209: 68-74.

[13] Walter, H. S. (1940). Purification of prothrombin and thrombin: chemical properties of purified preparations. J. Biol. Chem 136: 103-111. 